\title{
Plankton Distribution and Diversity in Tropical Earthen Fish Ponds
}

\author{
Gabriel Ujong Ikpi ${ }^{1}$, Benedict Obeten Offem ${ }^{1}$ \& Irom Bassey Okey ${ }^{1}$ \\ ${ }^{1}$ Department of Fisheries and Aquatic sciences, Cross River University of Technology, Obubra Campus, Cross \\ River State, Nigeria \\ Correspondence: Benedict Obeten Offem, Department of Fisheries and Aquatic sciences, Cross River University \\ of Technology, Obubra Campus, Cross River State, Nigeria. E-mail: benbeff06@yahoo.com
}

Received: February 6, 2013 Accepted: May 23, 2013 Online Published: May 28, 2013

doi:10.5539/enrr.v3n3p45

URL: http://dx.doi.org/10.5539/enrr.v3n3p45

\begin{abstract}
Our knowledge of the consumption of plankton by fish is still fragmentary. Trophic links between fish and plankton are often loose because plankton is a changing assemblage of pelagic organisms of valuable nutritional value. The objectives of the study were to determine the distribution and diversity of planktons in the fish ponds. Water samples for plankton analysis were collected monthly (January-December), along with water samples used for the determination of physico-chemical parameters in $250 \mathrm{ml}$ bottles in Ponds 1,2 and 5. The freshwater sample was mixed gently and pipetted into $5 \mathrm{ml}$ plankton chamber containing 2 drops of Lugol's solution. The Lugol's solution which served as fixative also enhanced sedimentation of the organisms and was left overnight before analyzing plankton using Zeiss inverted plankton microscope and plankton determination keys. Data was analyzed using Shannon-Weaner diversity index, species richness, means and analysis of varians (ANOVA). The results showed that the highest species richness for dry season phytoplankton value of 27 was recorded in Pond 2, with the highest Shannon-Weaner diversity index value of 0.5401 in pond 5. Merismopaedia elegans with 3,434 in pond 2 was the most abundant phytoplankton species and chlorophyceae the most dominant taxa. The rainy season zooplankton species richness values (5 in pond 2) were higher than that of the dry season (3 in pond 3) with the highest Shannon-Weaner index value of 0.3501 recorded in pond 1 . The most abundant zooplankton species Asplanchna species 57 was recorded in pond 2. Significant differences $(p<0.05)$ was observed for phytoplankton and zooplankton species between the ponds. Physico-chemical parameters had influence on the distribution and diversity of planktons in the fish ponds.
\end{abstract}

Keywords: plankton diversity, earthen fish ponds, tropical, physicochemical parameters

\section{Introduction}

The aquatic environment supports various communities of living organisms. They constitute the biotic load of a pond. Plankton designates the community of pelagic organisms, composed of various groups, which are in suspension in water and hence restricted mobility, often less than that of the water which carries (Declince, 1992). Plankton is divided into phytoplankton or photosynthetic organisms and zooplankton or heterotrophic organisms. The spectrum of phytoplankton found in ponds, consist of a large number of taxa. According to cell size, the following groups can be distinguished: picoplankton (from 0.02 to $0.2 \mu \mathrm{m}$ ) nanoplankton (from 0.2 to $2.0 \mu \mathrm{m}$ ) (Sieburth et al., 1978). Organisms over $20 \mu \mathrm{m}$ in size are called netplankton. Picoplankton and nanoplankton, often ignored in plankton studies can contribute significantly to primary productivity, often in excess of what their biomass would suggest (Hardy et al., 1986; Stockner \& Antia 1986; Stockner, 1988).

Zooplankton distribution within ponds is non-homogenous. In Dutch fish ponds, some species were mainly found in the littoral, while others selected limnetic waters (Verreth, 1990). Such distributions are probably related to food availability and avoidance of predators. Distribution varies with time, due in particular, to vertical migration, which is an almost universal phenomenon. The archetypical form of vertical migration is a swimming movement to deep water during the day and an active ascent towards the surface during the night (Declince, 1992). This diel movement from the warm, food-rich surface layers to the cold nutritionally poor deep waters has evolved in response to benefits to the community: (1) vertical migration results in predator avoidance by zooplankton; (2) fluctuations of the grazing pressure owing to vertical migration enables unimpeded growth of the algae during daytime. This results in higher rates of algal production, compared to those obtained in conditions where zooplanktons graze continuously on the same algal biomass. Zooplankton is subdivided, according to size, into microzooplankton, mesozooplankton and macrozooplankton. Microzooplankton are the 
smallest organisms, consisting of flagellates, ciliates and rotifers, mostly detritivorous and bactivorous, though rotifers also consume small algae. Mesozooplankton is comprised of cladocerans and macrozooplankton of copepods (or cladocerans and copepods). The dietary range of zooplankton organisms is often wider (Declince 1992). The objectives of the study is to determine the distribution and diversity of planktons in the fish ponds.

\section{Materials and Methods}

\subsection{Description of Study Area}

The Cross River University of Technology, Obubra Campus is located at Ovonum village of Obubra Local Government Area in the Central Senatorial District of Cross River State, Nigeria. The campus stands on a dissected Plateau which is bounded in the north by Ebonyi State, in the south by Ababene and Ofat Villages, in the east by Ofatura and Apiapum Villages and in the west by Ofodua Village all in Obubra Local Government Area.The latitude and longitude locations are $6^{\circ}$ and $8^{\circ} 15^{\prime} \mathrm{E}$ approximately. It is almost equidistant between the north and southern ends of the state and $156 \mathrm{~km}$ from Calabar the State capital.

\subsection{Plankton Analysis}

Water samples for plankton analysis were collected monthly (January to December), along with water samples used for the determination of physico-chemical properties, in a $250 \mathrm{ml}$ bottles, as in Ajani (2001). The water samples collected from ponds 1, 2 and 5 were taken to the Fisheries laboratory of Cross River University of Technology at Obubra Campus, for plankton analysis. Fresh water sample was mixed gently and pipetted into $5 \mathrm{ml}$ plankton chamber containing 2 drops of Lugol's solution. The Lugol's solution served as the fixative while also enhancing sedimentation of the organisms. The chamber was left overnight for complete sedimentation to take place. Plankton was analyzed using Zeiss inverted plankton microscope by the method described in UNESCO (1978), using plankton determination keys from Edmonton (1959), Prescott (1970), and Sharma (1986)

\subsection{Data Analysis}

Mean and standard deviation of each of the physico-chemical parameters were calculated. Analysis of variance (ANOVA) was used to test for statistical differences between the means of the physical and chemical parameters of the fish ponds. Diversity index which include Shannon-Weaner diversity index and species richness was used to determine the plankton species composition and their diversity across the different ponds sampled. Shannon-Weaner's Index (H) is commonly used to characterize species diversity in a community. Shannon-Weaner's Index accounts for both abundance and evenness of the species present. The proportion of species is relative to the total number of species $(P i)$ is calculated and then multiplied by the natural logarithm of this proportion $(\mathrm{LnPi})$. The resulting product is summed across species and multiplied by Equation 1:

$$
\mathrm{H}=-\sum_{i=1}^{s} P i \operatorname{Ln} P i
$$

\section{Results}

There was no significant difference in the values of the physico-chemical parameters of the three sampling sites (Table 1).

Table 1. Mean ( \pm SD) values of some physical and chemical characteristics of the three fishponds

\begin{tabular}{llll}
\hline Parameters & Pond 1 & Pond 2 & Pond 3 \\
\hline Surface Temperature $\left({ }^{\circ} \mathrm{C}\right)$ & $27.7 \pm 1.71 \mathrm{a}$ & $27.2 \pm 2.11 \mathrm{a}$ & $27.5 \pm 1.12 \mathrm{a}$ \\
Turbidity(NTU) & $34.2 \pm 2.32 \mathrm{a}$ & $32.5 \pm 3.12 \mathrm{a}$ & $33.4 \pm 7.23 \mathrm{a}$ \\
$\mathrm{Ph}$ & $6.8 \pm 0.66 \mathrm{a}$ & $6.8 \pm 0.12 \mathrm{a}$ & $6.8 \pm 1.81 \mathrm{a}$ \\
Dissolved Oxygen $\left(\mathrm{mg} . \mathrm{l}^{-1}\right)$ & $4.8 \pm 1.34 \mathrm{a}$ & $4.9 \pm 0.12 \mathrm{a}$ & $4.8 \pm 1.34 \mathrm{a}$ \\
Alkalinity $\left(\mathrm{mg} . \mathrm{l}^{-1}\right)$ & $41.2 \pm 4.42 \mathrm{a}$ & $40.8 \pm 5.43 \mathrm{a}$ & $41.5 \pm 4.34 \mathrm{a}$ \\
Conductivity $\left(\mu \mathrm{S} . \mathrm{cm}^{-1}\right)$ & $32.4 \pm 4.23 \mathrm{a}$ & $31.4 \pm 2.32 \mathrm{a}$ & $31.7 \pm 3.6 \mathrm{a}$ \\
BOD $\left(\mathrm{mg} . \mathrm{l}^{-1}\right)$ & $1.3 \pm 0.66 \mathrm{a}$ & $1.6 \pm 0.84 \mathrm{a}$ & $1.5 \pm 0.62 \mathrm{a}$ \\
Phosphates $(\mathrm{mg} / \mathrm{l})$ & $2.5 \pm 0.01 \mathrm{a}$ & $2.5 \pm 0.04 \mathrm{a}$ & $2.4 \pm 0.12 \mathrm{a}$ \\
\hline
\end{tabular}




\begin{tabular}{llll}
\hline Calcium $(\mathrm{Ca}++)$ & $10.4 \pm 3.4 \mathrm{a}$ & $9.3 \pm 2.87 \mathrm{a}$ & $10.4 \pm 1.83 \mathrm{a}$ \\
Magnesium $(\mathrm{Mg}++)$ & $1.6 \pm 0.22 \mathrm{a}$ & $1.1 \pm 0.54 \mathrm{a}$ & $1.2 \pm 0.99 \mathrm{a}$ \\
Total iron & $1.4 \pm 0.56 \mathrm{a}$ & $0.7 \pm 0.43 \mathrm{a}$ & $1.9 \pm 0.36 \mathrm{a}$ \\
Silicon $\left(\mathrm{SiO}_{2}\right)$ & $28.9 \pm 1.89 \mathrm{a}$ & $28.4 \pm 5.34 \mathrm{a}$ & $27.8 \pm 9.65 \mathrm{a}$ \\
Sulphates $\left(\mathrm{SO}_{4}^{-2}\right)$ & $11.4 \pm 1.23 \mathrm{a}$ & $12.8 \pm 2.88 \mathrm{a}$ & $11.8 \pm 3.31 \mathrm{a}$ \\
Nitrates $\left(\mathrm{NO}_{3}^{-}\right)$ & $0.2 \pm 0.18 \mathrm{a}$ & $0.3 \pm 0.14 \mathrm{a}$ & $0.2 \pm 0.16 \mathrm{a}$ \\
Chlorides $\left(\mathrm{Cl}^{-}\right)$ & $10.6 \pm 2.99 \mathrm{a}$ & $11.2 \pm 2.21 \mathrm{a}$ & $11.0 \pm 2.71 \mathrm{a}$ \\
Total hardness & $55.5 \pm 8.88 \mathrm{a}$ & $54.3 \pm 6.54 \mathrm{a}$ & $56.0 \pm 2.56 \mathrm{a}$ \\
Total solids $(\mathrm{mg} / \mathrm{l})$ & $66.6 \pm 5.34 \mathrm{a}$ & $67.6 \pm 3.76 \mathrm{a}$ & $68.3 \pm 5.30 \mathrm{a}$ \\
Total Dissolved solids $(\mathrm{mg} / \mathrm{l})$ & $58.8 \pm 7.54 \mathrm{a}$ & $57 . .5 \pm 4.66 \mathrm{a}$ & $57.2 \pm 6.41 \mathrm{a}$ \\
\hline
\end{tabular}

Values in the same rows with the same superscript are not significantly different $(\mathrm{p}>0.05)$.

Seasonal variation was observed in the values of physico-chemical properties of the ponds with some chemical properties like TS, TDS, TH and DO, showing higher values during the wet months, while others like $\mathrm{PO}_{4}, \mathrm{NH}_{3}$ and BOD were higher during dry (Table 2).

Table 2. Plankton Diversity in Earthen Fish Ponds of Cross River University of Technology at Obubra Campus for Dry Season (December-April, 2008)

\begin{tabular}{lccc}
\hline \multicolumn{1}{c}{ Fish Pond } & POND 1 & POND 2 & POND 3 \\
\hline Plankton Species & & & \\
\hline 1. Phytoplankton & & & \\
\hline a. Chlorophyceae & & & \\
$\quad$ Akinstrodesmus falcatus & 151 & 162 & 75 \\
Centritractus belanophorus & - & 81 & - \\
Ceriasteris irregular & - & 70 & - \\
Chlamydomonas ehrenbergii & 128 & 23 & 34 \\
Chlorella ellipsoidea & 3,364 & 372 & 113 \\
Euastrum pectinatum & - & 186 & 25 \\
Eudorina elegans & - & 23 & - \\
Micrasterias Americana & - & 11 & - \\
Oocystics species & - & 81 & 27 \\
Pediastrum simplex & - & 11 & 31 \\
Scenedesmus quadricuada & - & 35 & - \\
Scenedesmus species & - & 220 & - \\
Selenastrum gracile & - & 58 & 17 \\
Spinuclosterium curvatum & 11 & 418 & - \\
Staurastrum rotula & - & 104 & - \\
Tetraedron regulare & 46 & 128 & - \\
Ulothrix cylindricum & - & 81 & - \\
Volvox tertius & - & 11 & - \\
b. Bacillariophyceae & & & \\
Navicula pettersenii & - & 58 & 5 \\
Nitzchia species & - & 35 & - \\
\hline
\end{tabular}


c. Cyanophyceae

Anabeana spiroids

Merismopeadia elegans

Oscillatoria species

d. Euglenophyceae

Euglena rubra

Lepocynlis acuta

Trachelomonas volvocina

Trachelomonas ampula

Trachelomonas horida

e. Dinophyceae

Gymnodinium palustre

f. Cryptophyceae

Cryptomonas erosa

Species richness

Shannon Weaner diversity index

2. Zooplankton

a. Rotifera

Chromogaster species

Euchlanis species

Asplanchna species

b. Ciliata

Strombidium viride

Euplotes species

Species richness

Shannon Weaner diversity index $(\mathrm{H})$

$\begin{array}{ccc}- & 23 & - \\ - & 3,434 & 71 \\ - & 35 & 5\end{array}$

$\begin{array}{lll}70 & 255 & 12\end{array}$

$35 \quad-\quad$ -

$\begin{array}{lll}754 & 534 & 128\end{array}$

$23 \quad-\quad 37$

11 - $\quad-$

$\begin{array}{lll}- & 116 & 46\end{array}$

$139 \quad 23 \quad 15$

$\begin{array}{lll}11 & 27 & 15\end{array}$

$\begin{array}{lll}0.5401 & 0.2954 & 0.1156\end{array}$

\begin{tabular}{lccc}
$\quad$ Strombidium viride & 23 & 11 & - \\
$\quad$ Euplotes species & - & & 3 \\
Species richness & 2 & 2 & 3 \\
Shannon Weaner diversity index $(\mathrm{H})$ & 0.5623 & 0.5 & 0.3689 \\
\hline
\end{tabular}

\subsection{Plankton}

30 species of phytoplankton belonging to 6 families were recovered from the ponds during study period. The largest family was Chlorophyceae contributing 18 species, followed by Euglenophyceae with 5 species and the least were Dinophyceae and Cryptophyceae contributing one species each. The zooplankton had 5 species belonging to 2 families; Rotifera and Ciliata. The rotifers consist of Chromogaster, Euchlanis and Asplanchna species while the ciliates had Strombidium viride and Euplotes.

The occurrence of plankton species showed that values for phytoplankton were significantly higher during the dry season than the wet for most of the species (Figure 1) while the opposite was the case for zooplankton values (Figure 2).

\subsection{Plankton Diversity in Dry Season}

Phytoplankton richness index was highest in Pond 2 (27) and least in pond 1 (11) but Shannon-Weaner's diversity index showed highest values (0.5401) in Pond 1 and lowest in Pond 3 (Table 3). Richne index for zooplankton was low in all the ponds with no significant differences $(\mathrm{P}>0.05)$ in Shannon-Weaner diversity values.

\subsection{Plankton Diversity for Rainy Season}

Wet season Phytoplankton richness $(8,24$ and 13$)$ and diversity values $(0.4330,0.3042$ and 0.0943$)$ were low in all ponds $(1,2,3)$ respectively. On the other hand, zooplankton richness (4 for pond 1,5 for pond 2 and 4 for pond 5) and Shannon-Weaner values for pond 1 (0.3501), Pond 2 (0.2409) and Pond 3 (0.2966) were significantly higher than dry. 


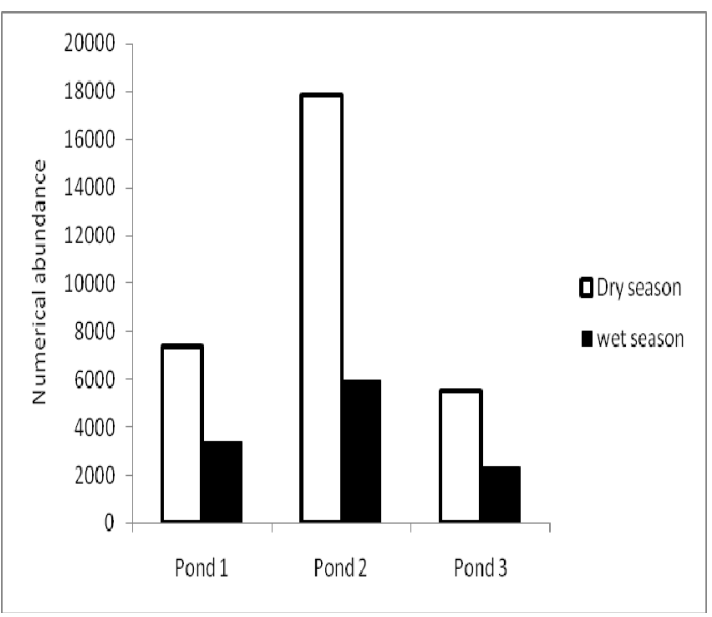

Figure 1. Abundance of phytoplankton during wet and dry seasons

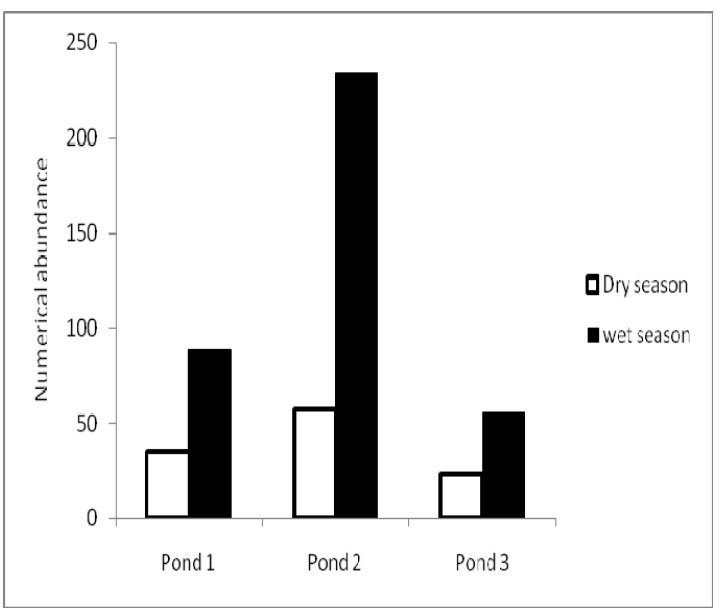

Figure 2. Numerical abundance of zooplankton during dry and wet season

\section{Discussion}

Physico-chemical parameters of water body serve as measure of water quality (Offem, 2008). Changes in the intensity of rainfall affects physico-chemical parameters of water which also affects biomass of aquatic organisms (Adebisi, 1981). The higher turbidity, salinity, TDS and most of the physico-chemical properties in the wet season had been explained to be as a result of flooding during heavy rainfall and run-off from nutrient rich agricultural lands increased (Ayodele \& Ajani 1999; Offem, 2008). Lower dissolved oxygen values obtained during dry season could probably be due to higher temperatures during the season (Akpan \& Offem, 1993a) while high levels of dissolved oxygen during the wet season could be due to lower water temperature and increased aeration due to agitation by wind in the wet season (Ochang et al., 2005). High organic enrichment of ponds during the dry season may be responsible for such low oxygen values that might have increased ionic substances such as nitrate, chloride and phosphate from fertilizers (Offem, 2008).

The Composition of phytoplankton community of the ponds agreed with reports that blue-green algae and green algae dominate most tropical water bodies (Adebisi, 1981; Ayodele \& Ajani, 1999). Increased temperature, sunlight and tropholytic activities as a result of low water level coupled with frequent movement of water from the deep, nutrient-rich sediments into the tropholytic zone, increased the abundance of phytoplankton during dry season. Dominance of Chlorophyceae in the ponds in the dry season had been attributed to the presence of sunshine and extensive catchment area draining phosphate rich agriculture land (Uttah, 2008; Kurasawa \& Shiraishi, 1954). Also flexibility in the Physiology and behaviour of Chlorophyceae can tolerate environmental changes better than other species (Silva, 2004). The observation in the ponds agree with findings by Utah (2008) that the phytoplankton biomass increase with increase in transparency, frequently associated with dry season, while the high turbidity frequent with the wet season results in a reduction of biomass. It was also reported in ponds in Asia, where phytoplankton scarcity can be observed during the wet months (Silva, 2004) and most of the ponds in India where three plankton pulses occur within the dry season. During the wet months flushing disturbs the standing crop of plankton. However, when the destabilising effect reduces, the accumulated nutrient input favours an increased plankton production during the dry.

The high population density of the zooplankton during the rainy season may be as a result of abundant food source from run-off through nutrient-rich agricultural lands. It has been reported that increase in primary production (phytoplankton), is accompanied by increase in zooplankton abundance (Rocha et al., 1999). Also, it had been observed that zooplankton abundance frequently reach their peak during the wet season in ponds (Muylaert et al., 2003). Besides food sources, low predation rate by fish during the wet season caused by their increased breeding activities could encouraged high population density of the zooplankton.

The zooplankton population dominated by rotifers in the wet season and ciliates in the dry season in all the ponds was similar to earlier findings (Egborge, 1981b). The alternation in abundance between rotifers and ciliates as shown in the seasonal distribution and abundance of zooplankton in the sampled ponds was regarded as a booster of all year round food for fish in the lake (Egborge, 1981b). This study showed that the seasonal variation in zooplankton concentration could largely be due to the Rotifera which normally constitute major diet 
items of larger zooplankton.

\section{Conclusion}

The study has shown that phytoplankton were more abundant during the dry season than the wet season, while occurrence zooplankton was more during the wet season than the dry. There was seasonal variation in the physico-chemical parameters of the pond water which in turn influenced the distribution and abundance of phytoplanktons and zooplanktons.

\section{Reference}

Adebisi, A. A. (1981). The physico-chemical hydrology of tropical seasonal river upper Ogun River. Hydrobiologia, 79, 157-165. http://dx.doi.org/10.1007/BF00006123

Ajani, E. K. (2001). Effects of biotic and abiotic components of the habitat on fish productivity in Lagos Lagoon, Nigeria Ph.D Thesis University of Ibadan. p. 277.

Akpan, E. R., \& Offem, J. O. (1993a). Seasonal variation in water quality of the Cross River State Nigeria Hydrobiologia, 26, 95-103.

Ayodele, I. A., \& Ajani, E. K. (1999). Essentials of fish farming (aquaculture). Odufuwa publishers, Ibadan.

Declince, G. (1992). The ecology of the fish pond ecosystem. (pp. 127-187). Kluwer Academic Publishers. http://dx.doi.org/10.1007/978-94-017-3292-5_4

Egborge, A. B. M. (1981b). The composition, seasonal variation and the distribution of zooplankton in Lake Asejire, Nigeria. Revue de Zoologie Africaine, 95, 136-144.

Edmonton, W. T. (1959). Freshwater biology (2nd ed.) (p. 1248). New York: John Wiley and Sons.

Hardy, F. J. Shortreed, K. S., \& Stockner, J. G. (1986). Bacterioplankton, phytoplankton and zooplankton communities in a British Columbia Coastal Lake before and after nutrient reduction. Can J. Fish Aquat. Sci., 43, 1504-1514. http://dx.doi.org/10.1139/f86-188

Kurasawa, H., \& Shiraishi, Y. (1954). Studies on the biological production of Lake Suwa. Research Institute of Natural Resources, 33, 22-57.

Mustapha, M. K. (2009). Zooplankton assemblage of Oyun Reservoir, Offa, Nigeria. Nig. J. Aquat. Sci., 9, 1-14.

Muylaert, K. S., Declerck, V., Geenens, J. V., Wichelen, H., Deegans, J., Vandekerkhove, K. V., .. Vyverman, W. (2003). Zooplankton, phytoplankton and the microbial food web in two turbid and two clear shallow lakes in Belgium. Aquat. Ecol., 37, 137-150. http://dx.doi.org/10.1023/A:1023988702926

Ochang, S. N., Ayotunde, E. O., \& Okey, I. B. (2005). Some aspects of the physico-chemical and biological properties of Cross River, an inland water body in South-Eastern Nigeria. Glob. J. Agric. Sci., 4(2), $139-148$.

Offem, B. O., Akegbejo- Samsons, Y., Omoniyi, I. T., \& Ikpi, G. U. (2008). Dynamics of the limnological features and diversity of zooplankton populations of the Cross River System SE Nigeria. Knowledge and Management of Aquatic Ecosystems, 393, 2-19.

Prescott, G. W. (1970). How to know freshwater algae (p. 348). W.M.C. Brown Company Publishers.

Rocha, O., Matsumura-Tundisi, Y. T., Espindola, E. L. G., Roche, K. F., \& Rietzler, A. C. (1999). Ecological theory applied to reservoir zooplankton, In J. G. Tundisi \& M. Straskraba (Eds). Theoretical reservoir ecology and its applications (pp. 29-51). International Institute of Ecology, Brazilian Academy of Sciences. Backhugs publishers, Leiden, Holland.

Sharma, O. P. (1986). Text book of algae (p. 396). New Delhi: TATA Mcgrawhill publishing Comp. Ltd.

Sieburth, J., Mc, N., Smetacek, V., \& Lenz, J. (1978). Pelagic ecosystem structure: heterotrophic compartments of the plankton and their relationship to plankton size fractions. Limnol Oceanogr, 23, 1256-1263. http://dx.doi.org/10.4319/lo.1978.23.6.1256

Silva, E. I. L. (2004). Phytoplankton Characteristics, Trophic Evolution and Nutrient Dynamics in an Urban Eutrophic Lake: Kandy Lake in Sri Lanka. In M. V. Reddy (Ed.), Restoration and Management of Tropical Eutrophic Lakes (pp. 219-260). New Delhi: Oxford and IBH Publishing.

Stockner, J. G. (1988). Phototrophic picoplankton: an overview from marine and freshwater ecosystems. Limnol. Oceanogr, 33, 765-775. http://dx.doi.org/10.4319/lo.1988.33.4_part_2.0765

Stockner, J. G., \& Antia, N. J. (1986). Algal Picoplankton from marine and freshwater ecosystem: a 
multidisciplinary perspective. Can. J. Fish. Aquat. Sci., 43, 2472-2503. http://dx.doi.org/10.1139/f86-307

UNESCO. (1978). Phytoplankton manual (p. 337). Paris: UNESCO.

Uttah, E. C., Uttah, C., Akpan, P. A., Ikpeme, E. M., Ogbeche, J., Usip, L., \& Asor, J. (2008). Bio-survey of plankton as indicators of water quality for recreational activities in Calabar River, Nigeria. J. Appl. Sci. Environ. Manage, 12(2), 35-42.

Verreth, J. (1990). The accuracy of population density estimates of a horizontally distributed zooplankton community in Dutch fish ponds. Hydrobiologia, 203, 53-61. http://dx.doi.org/10.1007/BF00005613

\section{Copyrights}

Copyright for this article is retained by the author(s), with first publication rights granted to the journal.

This is an open-access article distributed under the terms and conditions of the Creative Commons Attribution license (http://creativecommons.org/licenses/by/3.0/). 